\title{
Hydrological and hydrochemical observation status in the pan-Arctic drainage basin
}

\author{
Arvid Bring \& Georgia Destouni \\ Department of Physical Geography \& Quaternary Geology, Stockholm University, SE-106 91 Stockholm, Sweden
}

\author{
Keywords \\ Discharge; hydrochemistry; hydrology; \\ monitoring; pan-Arctic drainage basin; \\ water chemistry.

\section{Correspondence} \\ Arvid Bring, Department of Physical \\ Geography \& Quaternary Geology, Stockholm \\ University, SE-106 91 Stockholm, Sweden. \\ E-mail: arvid.bring@natgeo.su.se
}

doi:10.1111/j.1751-8369.2009.00126.x

\begin{abstract}
In order to identify and understand the ongoing changes in the Arctic hydrological cycle, and the impacts on the Arctic Ocean, timely and open access to water and water-chemistry data is essential. By synthesizing and analysing all openly accessible water-discharge and water-quality data, we present an updated, quantitative picture of the status of observational data on hydrological and hydrochemical fluxes from the pan-Arctic drainage basin (PADB) to the ocean. We identify and compare the characteristics of monitored and unmonitored areas, and the differences between them, across the continents in the PADB. Results indicate significant gaps in monitoring data for water chemistry, in particular for high-latitude near-coastal areas. The differences in characteristics between monitored and unmonitored areas may bias assessments of hydrological and hydrochemical fluxes to the Arctic Ocean. The reliable identification and understanding of important biogeochemical processes in the PADB require extended monitoring, particularly in high-latitude permafrost ground, and more ready access to harmonized and integrated hydrochemical data.
\end{abstract}

The Arctic hydrological cycle is an integral part of the climate system, both in the Arctic region itself through its integration of terrestrial, atmospheric and human systems with the Arctic Ocean (Vörösmarty et al. 2001), and globally through its connections to worldwide ocean circulation and climate feedback mechanisms (Houghton et al. 2001). Recently observed rapid and significant changes to the Arctic water cycle, including the shorter extent of the snow-cover season (Serreze et al. 2000), increasing river run-off (Peterson et al. 2002) and increasing precipitation (Houghton et al. 2001), may indicate that the region is in transition to a state not previously observed in recent history (Hinzman et al. 2005).

In order to identify and monitor the freshwater fluxes from land to the Arctic Ocean, and to understand the ongoing changes in the Arctic hydrologic cycle in general, access to reliable environmental data is of paramount importance. Most long-term river monitoring data are collected by government agencies, which, with limited budgets, must address a range of partially conflicting information goals. Therefore, the spatial distribution and extent of stations in the monitoring networks are not likely to be optimized for the specific needs of the end users of the monitoring data. For instance, the freshwater fluxes from land to sea would be optimally monitored by prioritizing the most downstream stations of the main rivers. However, with regard to the waterborne nutrient and pollutant mass fluxes from land to sea, the small, unmonitored and often heavily populated near-coastal catchment areas, along the extended coastline stretches between the main rivers, may yield as large or larger mass fluxes as are observed for the major monitored rivers (Destouni et al. 2008). The process-based understanding of hydrological changes within catchments, on the other hand, requires monitoring across a range of different inland catchments of varying characteristics (Sidle 2006; Soulsby et al. 2006).

In all cases, water-monitoring data are necessary both for establishing a baseline of past states and trends, in relation to which comparisons can be made, and for calibrating models and observing the current changes to hydrological systems. Unfortunately, factors such as its harsh climate, long distances and low population density limit the availability of water-monitoring data for the Arctic. Recent discussions of the global status of hydrological monitoring programmes (Brown 2002; Fekete $\&$ Vörösmarty 2002; Maurer 2003; GCOS 2005; Hannerz 
2008) have indicated severe problems of data availability and accessibility. Stations are being closed, and data are delayed, incomplete or not disseminated. Where monitoring the status in Arctic regions in particular is mentioned (e.g., Lammers et al. 2001; Shiklomanov et al. 2002; Hinzman et al. 2005; Walsh et al. 2005), the situation is also described as worrying. In particular, there is a lack of monitoring of water chemistry (Holmes et al. 2002; Prowse et al. 2005), and data quality is also an issue in some cases (Holmes et al. 2000; Zhulidov et al. 2000; Holmes et al. 2001). Furthermore, the state of monitoring in the Arctic is deteriorating, and data-gathering systems continue to decline across the region (GCOS 2005).

Nevertheless, significant efforts have been made to harmonize and increase the accessibility to discharge data. There are currently at least four international discharge databases with data for the pan-Arctic region: the Arctic Runoff Database (ARDB), administered through the Global Runoff Data Centre in Koblenz, Germany; the Regional, Hydrometeorological Data Network for the Pan-Arctic Region (R-ArcticNET); the Arctic Rapid Integrated Monitoring System (ArcticRIMS); and the Global River Discharge Database (RivDis), which is an older global discharge database. These international databases are well known to the scientific community, and have been used extensively for water balance modelling and studies of freshwater input to the Arctic Ocean (e.g., Peterson et al. 2002; Berezovskaya et al. 2004; Peterson et al. 2006). However, in order to quantify mass fluxes of, for example, carbon and nutrients, water chemistry monitoring in concert with water discharge monitoring is crucial. Unfortunately, such data for the Arctic region are even less available than run-off data (Holmes et al. 2002). There have been many process-level studies of individual sites or smaller basins (Vörösmarty et al. 2001), but studies are lacking that support the development of a comprehensive strategy for a continuous monitoring of biogeochemical mass fluxes in the Pan-Arctic drainage.

In light of the ongoing decline of available and accessible monitoring data, it is important to analyse the effects of this decline on the reliability of downstream analyses based on such data. It is important to investigate whether there are any systematic differences between the characteristics of the monitored and the unmonitored areas draining into the Arctic Ocean. Such differences may bias the assessments of chemical mass fluxes to the ocean, in addition to just not resolving them sufficiently, and thereby significantly affect the accuracy-and not just the precision-of hydrologic modelling across basins with different properties.

The present study aims to establish a comprehensive quantitative picture of the current status of accessible monitoring data for water discharge, and waterborne mass fluxes, from the pan-Arctic drainage basin (PADB) to the Arctic Ocean. Furthermore, the study aims to characterize the monitored and the unmonitored coastal catchment areas within the PADB, and their potential systematic differences with regard to various properties that are relevant for the hydrological and hydrochemical fluxes from land to sea. This information could indicate whether the monitoring data presently available adequately capture the prevailing variation in hydrological and hydrochemical parameters in the drainage to the Arctic Ocean. Our analysis constitutes a first-order assessment and analysis of areas where the lack of monitoring may be most critical. Further studies are needed to address more specific monitoring issues, such as the optimal placement of new stations for different scientific goals, environmental and resource management targets or adaptation to change.

\section{Material and methods}

Openly accessible monitoring data for freshwater discharge were gathered from four established international discharge databases: the ARDB (GRDC 2006), R-ArcticNET (Lammers et al. 2001), ArcticRIMS (ArcticRIMS 2007) and RivDis (Vörösmarty et al. 1998). To synthesize water-chemistry data, the meta-databases of the US National Snow and Ice Data Centre (NSIDC 2006), the Arctic Climate System Study Data and Information Service (ADIS 2006), the Global Observing Systems Information Centre (GOSIC 2006) and the Global Runoff Data Centre (GRDC 2006) were systematically examined, and databases with accessible water-chemistry data were identified. From these databases, all accessible waterchemistry data for stations within the PADB were subsequently gathered.

For all monitoring programmes, the extracted data sets were processed to summarize records of series length, first operational year and latest available data year for each monitoring station. The accessible water chemistry parameters were grouped into the following categories: carbon, sediment, nitrogen and phosphorus. Stations missing location information were removed, as were stations without data and stations outside the PADB. The file formats of data varied widely, and required significant programming and database operations in order to extract the desired information. The most common formats of data were either text files with various structures, or Microsoft Excel spreadsheets. One monitoring programme, the United Nations Global Environment Monitoring System Water Program (GEMS/Water), did not provide raw data, and the information from this monitoring programme was summarized manually from inspecting a multitude of graphs on the programme's 
website (GEMStat 2007). To clearly identify which years had accessible data, graphs displaying aggregated values in yearly box plots were used.

Monitored and unmonitored catchment areas were identified by co-referencing monitoring stations to the $30^{\prime} \times 30^{\prime}$ STN-30p drainage network (Simulated Topological Network; Vörösmarty et al. 2000). For stations with listed drainage areas smaller than five cells, the watersheds were considered too small for delineation using the drainage network. Cells containing such stations were instead classified as partly monitored if they fell outside the area otherwise identified as monitored by stations with larger drainages. This translates to minimum watershed areas for drainage delineation ranging from $4000 \mathrm{~km}^{2}$ at a latitude of $75^{\circ} \mathrm{N}$ to $10000 \mathrm{~km}^{2}$ at a latitude of $50^{\circ} \mathrm{N}$. Stations without drainage area information available from the data source were also removed if their drainage was smaller than five cells in the topological network.

The co-referencing of stations with the $30^{\prime}$ drainage network was performed through comparison of station locations with the $30^{\prime}$ network, and also with a river network of higher spatial resolution from the Hydrolk database (US Geological Survey 1998), to aid the interpretation of the station co-referencing with the 30' network. The listed drainage area for each station was compared with the simulated drainage area of the $30^{\prime}$ network. All stations with a difference of more than $10 \%$ between listed and simulated drainage areas were manually inspected. The stations were relocated to nearby cells with better agreement between simulated and listed areas, where this was possible, and were otherwise deleted. Stations for which visual inspection revealed a poor degree of representation in the $30^{\prime}$ network were removed.

It would be desirable to develop the assessment of the characteristics of basins to a finer scale than $30^{\prime}$. However, even though the coordinates of many stations are given to the precision of $0.01^{\circ}$ (equal to $36^{\prime \prime}$ or $0.6^{\prime}$ ), which is sufficient for continent- and regional-scale analysis, a quick visual inspection of these locations together with the Hydrolk 30" drainage network showed that many position errors are much larger. This indicates that the station coordinates cannot be taken to be accurate to the last digit. A substantial effort at improving the accuracy of station coordinates, in particular for stations in Russia, would be necessary for run-off and water chemistry modelling at finer resolutions.

In order to present a pan-Arctic overview of the extent of accessible data, maps that show the maximum length of data series and the last data year accessible, for all parameters, were produced. To produce these maps, the final delineation of watersheds was carried out in the following manner. For each station, the maximum accessible length of time series was determined. For all stations sharing the same value of their time series length, the combined monitored drainage area of that set of stations was identified. All raster cells within this combined monitored drainage area were given the associated, same value of time series length. The raster maps from repeated steps of this procedure were further combined, keeping the maximum value of data series length for each cell. This resulted in a final map in which each cell has a value of the longest data series available for that cell. An analogous procedure was applied to generate a map with the latest data year available for all cells.

Since the investigated databases were not mutually exclusive, many stations occur in more than one database, sometimes with different coordinates even for obvious cases of identical stations. No attempt was made at correcting these coordinate errors, as no data were available that would improve the precision of the station coordinates. However, the impact is most likely to be limited, as the main use of station data was to quantify monitored areas. A station occurring in more than one database with the same length of data and end year would not affect results, as the monitored areas overlap.

In order to identify potential biases in the monitoring coverage representation of hydrologic properties, the area-weighted distribution of distance to ocean, population, economic production, built-up land, vegetation zones, snow depth, ground ice, permafrost, soil organic carbon and soil moisture were summarized and averaged across unmonitored and monitored areas in North America, Europe and Asia. Differences in characteristics were also summarized by calculating the quotients between average values for unmonitored and monitored areas.

The distance to ocean was based on data from STN-30p (Vörösmarty et al. 2000), which in turn are based on the physical transport path of water through the simulated stream network. For calculation of population and population density, the Gridded Population of the World database (CIESIN 2007), produced by Columbia University's Earth Institute, was used. The economic production data were based on the Geographically Based Economic Data (G-Econ) database (Nordhaus 2006), which has a resolution of $1 \times 1^{\circ}$. For each $0.5 \times 0.5^{\circ}$ grid cell, one quarter of the gross cell product of the overlapping G-Econ cell was assigned to it. The gross cell product in the G-Econ data is expressed in terms of 1995 US dollars at purchasing power parity (PPP) exchange rates. As prices of similar goods vary between countries, PPP rates allow a direct comparison of the value of production in different economies, in contrast to market exchange rates. Estimates of the economic production in some remote areas may be 
significantly lower than actual values, as both the economic value and the extent of Arctic hydrocarbon exploration in remote areas has intensified significantly in the past decade (Walker et al. 2006). The G-Econ methodology, which is based on regional production per capita distributed according to population patterns, may not have incorporated the vast economic values added by the Siberian gas fields, but we estimate that it may still provide a sufficient basis for estimating the spatial distribution of economic production.

The built-up land data were compiled by Miteva (2001), based on DMSP/OLS night-time lights imagery and the International Geosphere-Biosphere Programme land cover classification. The vegetation-zone data were based on the World Wildlife Fund's Terrestrial Ecoregions GIS Database (Olson et al. 2001), which categorizes global land areas into 16 categories, of which nine are represented in the PADB. Average annual snow-depth data, based on climatologies for the period 1950-1999 (Willmott \& Matsuura 2001), were downloaded from the Atlas of the Biosphere project (SAGE 2007) at the University of Wisconsin. The data are on a natural logarithmic scale, representing the average annual snow depth in $\mathrm{mm}$.

Ground ice and permafrost information was taken from a United Nations Environment Program GRID-Arendal digitized version of a circum-Arctic map of permafrost and ground ice (Brown et al. 1998), which in turn is based on a paper map prepared by Brown et al. (1997) for the International Permafrost Association. Ground ice is categorized into high, medium or low for lowland topography, and high/medium or low for highland and mountainous topography. High ground ice content is defined as more than $20 \%$ visible ice (by volume) in the upper $10-20 \mathrm{~cm}$ of the ground, medium is defined as $10-20 \%$ and low is defined as less than $10 \%$. The permafrost extent is categorized according to the percentage of area underlain by permafrost, with continuous permafrost corresponding to $90-100 \%$ cover, discontinuous to $50-90 \%$ cover, sporadic to $10-50 \%$ cover and isolated patches to $0-10 \%$ cover.

The soil organic-content data were downloaded from the Atlas of the Biosphere (SAGE 2007), where the data are based in turn on the SoilData programme of the International Geosphere-Biosphere Programme Data and Information Services (Global Soil Data Task Group 2000). The soil-moisture data, based on climatologies for the period 1950-1999 (Willmott \& Matsuura 2001), and a soil water holding capacity of $150 \mathrm{~mm}$, were downloaded from the Atlas of the Biosphere project (SAGE 2007) at the University of Wisconsin.

We identified six databases with accessible waterchemistry monitoring data for the PADB. These are the Pan-Arctic River Transport of Nutrients, Organic Matter, and Suspended Sediments (PARTNERS) project (PARTNERS 2008; McClelland et al. 2008), GEMS/Water (GEMStat 2007), Eurasian River Historical Nutrient and Sediment Flux Data (Holmes \& Peterson 2002), HYDAT (Environment Canada 2004), European Waterbase (European Environment Agency 2006) and the US Geological Survey National Water Information System (US Geological Survey 2007). Apart from the international efforts of PARTNERS and GEMS/Water, water-chemistry data reside only in national and regional databases, with significant variation in data format and availability.

\section{Results}

Table 1 lists the parameters used from each waterchemistry monitoring programme, for each of the main investigation parameters. When several parameters for a monitoring programme were deemed relevant, more than one was included. Table 2 presents an overview of the accessibility to, and the characteristics of, the water-quality parameters of all five databases. The basin characteristics differ quite markedly between monitoring programmes, and between different continents. In $\mathrm{R}$-ArcticNET, the typical basin is most likely to be a few thousand square kilometres in size, and has a discharge record of around 20 years. A typical nitrogen-monitored basin in GEMS/Water or the Eurasian River Historical Nutrient and Sediment Flux Data Set databases (if such a basin can be said to exist, based on the small number of stations), on the other hand, is probably at least a few hundred thousand square kilometres in size, with a record of around 14 years. Furthermore, the aggregation period varies significantly between databases. Some databases provide data from individual samples, but most provide averaged or representative values for a certain period, ranging in length from daily to annual.

Figure 1 shows an overview of the spatial and temporal extent of the monitoring of water, carbon, nitrogen, phosphorous and sediment fluxes. Accessible waterdischarge data are significantly more extensive than water-chemistry data, particularly in temporal extent, but also spatially. However, even the water-discharge monitoring covers no more than $73 \%$ of the ice-free area draining to the Arctic Ocean, with the majority of the unmonitored areas occurring in the Arctic Archipelago, and in the northern regions of Asia. Nitrogen and phosphorus monitoring cover $62 \%$ of the non-glaciated Arctic Ocean drainage basin area, sediment monitoring covers $63 \%$ and carbon monitoring covers $51 \%$. The average length of time series for water-chemistry data is much shorter than that for water discharge for all continents (Fig. 1). The accessibility of recent water-chemistry data, on the other hand, is better, and is almost on a par 
Table 1 Water chemistry parameters for different monitoring programmes.

\begin{tabular}{|c|c|c|c|c|}
\hline Monitoring programme & Carbon & Nitrogen & Phosphorus & Sediment \\
\hline GEMS & $\begin{array}{l}\text { - Carbon-total organic } \\
\left(\mathrm{mg} \mathrm{l}^{-1} \mathrm{C}\right)\end{array}$ & $\begin{array}{l}\text { Nitrogen, nitrate + } \\
\text { nitrite }\left(\mathrm{mg} \mathrm{l}^{-1} \mathrm{~N}\right) \\
\text { - Nitrate }\left(\mathrm{mg} \mathrm{l}^{-1} \mathrm{~N}\right)\end{array}$ & 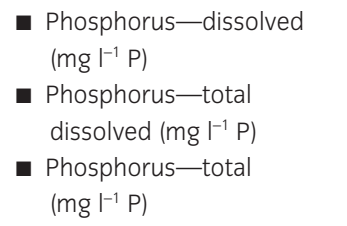 & $\begin{array}{l}\text { - Fixed suspended solids } \\
\left(\mathrm{mg} \mathrm{l}^{-1}\right) \\
\text { - Suspended solids } 105^{\circ} \mathrm{C} \\
\left(\mathrm{mg} \mathrm{l}^{-1}\right)\end{array}$ \\
\hline $\begin{array}{l}\text { Eurasian Rivers } \\
\text { data set }\end{array}$ & $\mathrm{N} / \mathrm{A}$ & $\begin{array}{l}\text { - Monthly } \mathrm{NH}_{4}-\mathrm{N} \\
\text { concentrations }\left(\mathrm{mg} \mathrm{l}^{-1}\right) \\
\text { - Monthly } \mathrm{NO}_{3}-\mathrm{N} \\
\text { concentrations }\left(\mathrm{mg} \mathrm{l}^{-1}\right)\end{array}$ & $\begin{array}{l}\text { - Monthly } \mathrm{PO}_{4}-\mathrm{P} \\
\text { concentrations }\left(\mathrm{mg}^{-1}\right)\end{array}$ & $\begin{array}{l}\text { - Monthly sediment load } \\
\left(\mathrm{kg} \mathrm{s}^{-1}\right)\end{array}$ \\
\hline HYDAT & $N / A$ & $\mathrm{~N} / \mathrm{A}$ & $\mathrm{N} / \mathrm{A}$ & $\begin{array}{l}\text { - Mean suspended sediment } \\
\left.\text { concentration (mg }\left.\right|^{-1}\right)\end{array}$ \\
\hline $\begin{array}{l}\text { National Water } \\
\text { Information } \\
\text { system (USGS) }\end{array}$ & $\begin{array}{l}\text { Organic carbon, water, } \\
\text { unfiltered }\left(\mathrm{mg} \mathrm{I}^{-1}\right) \\
\text { Organic carbon, water, } \\
\text { filtered }\left(\mathrm{mg} \mathrm{I}^{-1}\right) \\
\text { Inorganic carbon, } \\
\text { suspended sediment, } \\
\text { total }\left(\mathrm{mg} \mathrm{I}^{-1}\right) \\
\text { Organic carbon, } \\
\text { suspended sediment, } \\
\text { total (mg l-1) } \\
\text { Carbon (inorganic plus } \\
\text { organic), suspended } \\
\text { sediment, total (mg }{ }^{-1} \text { ) }\end{array}$ & $\begin{array}{l}\text { - Nitrate, water, filtered } \\
\text { (mg l-1 as nitrogen) } \\
\text { - Nitrate, water, filtered } \\
\left(\mathrm{mg} \mathrm{l}^{-1}\right)\end{array}$ & $\begin{array}{l}\text { - Phosphorus, water, filtered } \\
\left(\mathrm{mg} \mathrm{l}^{-1}\right) \\
\text { Orthophosphate, water, } \\
\text { filtered, (mg l-1 as } \\
\text { phosphorus) }\end{array}$ & $\begin{array}{l}\text { - Suspended sediment } \\
\text { concentration }\left(\mathrm{mg} \mathrm{l}^{-1}\right)\end{array}$ \\
\hline $\begin{array}{l}\text { Waterbase-Rivers } \\
\text { data set, version } \\
6 \text { (EEA) }\end{array}$ & $\begin{array}{l}\text { - Total organic carbon } \\
\left(\mathrm{mg} \mathrm{l}^{-1}\right)\end{array}$ & - Total nitrogen $\left(\mathrm{mg}^{-1} \mathrm{~N}\right)$ & $\begin{array}{l}\text { - Total phosphorus } \\
\left(m g \mathrm{I}^{-1} \mathrm{P}\right)\end{array}$ & $\mathrm{N} / \mathrm{A}$ \\
\hline
\end{tabular}

with the accessibility of water-discharge data, except for south-central Canada and northern Asia (Fig. 2). The best-monitored continent on average is Europe, except for sediment, where Asian areas have both longer records and more recent data, and the accessibility to current water-discharge data, where Asia also has more recent data.

Figure 3 summarizes the differences in area-weighted characteristics between unmonitored and monitored areas for the continents in the pan-Arctic drainage, and for different monitoring parameters, expressed as quotients between the area-weighted average values of the studied basin properties. For characteristics related to anthropogenic impacts (population density, average gross cell product and built-up land), North America systematically exhibits the highest quotients between monitored and unmonitored areas. Monitored areas in North America are therefore the most biased towards including more population- and production-rich catchments than prevail on average in the PADB part of the continent. In contrast, accessible European carbon monitoring is biased towards including catchments that are sparsley populated and close to the ocean. The Asian monitoring quotients generally fall between North America and Europe in the balance of anthropogenic pressures.

With respect to vegetation zones, boreal forests and taiga are over-represented in monitored areas, and under-represented in unmonitored areas, particularly in Asia. Temperate grasslands are much more prevalent in monitored than in unmonitored areas in North America, whereas their occurrence is balanced in Asian monitoring. Areas of tundra and continuous permafrost are strongly under-represented in the monitored areas, and the average annual snow depth is much lower in the monitored than in the unmonitored areas on all continents. Soil carbon and moisture are the most wellbalanced characteristics, even though the quotient between monitored and unmonitored areas for these parameters can still amount to more than $\pm 20 \%$.

\section{Discussion}

The synthesis of accessible discharge and water-chemistry data shows a wide range in aggregation time, average time series length and basin size between monitoring programmes (Table 2 ). This may reflect variations in the 


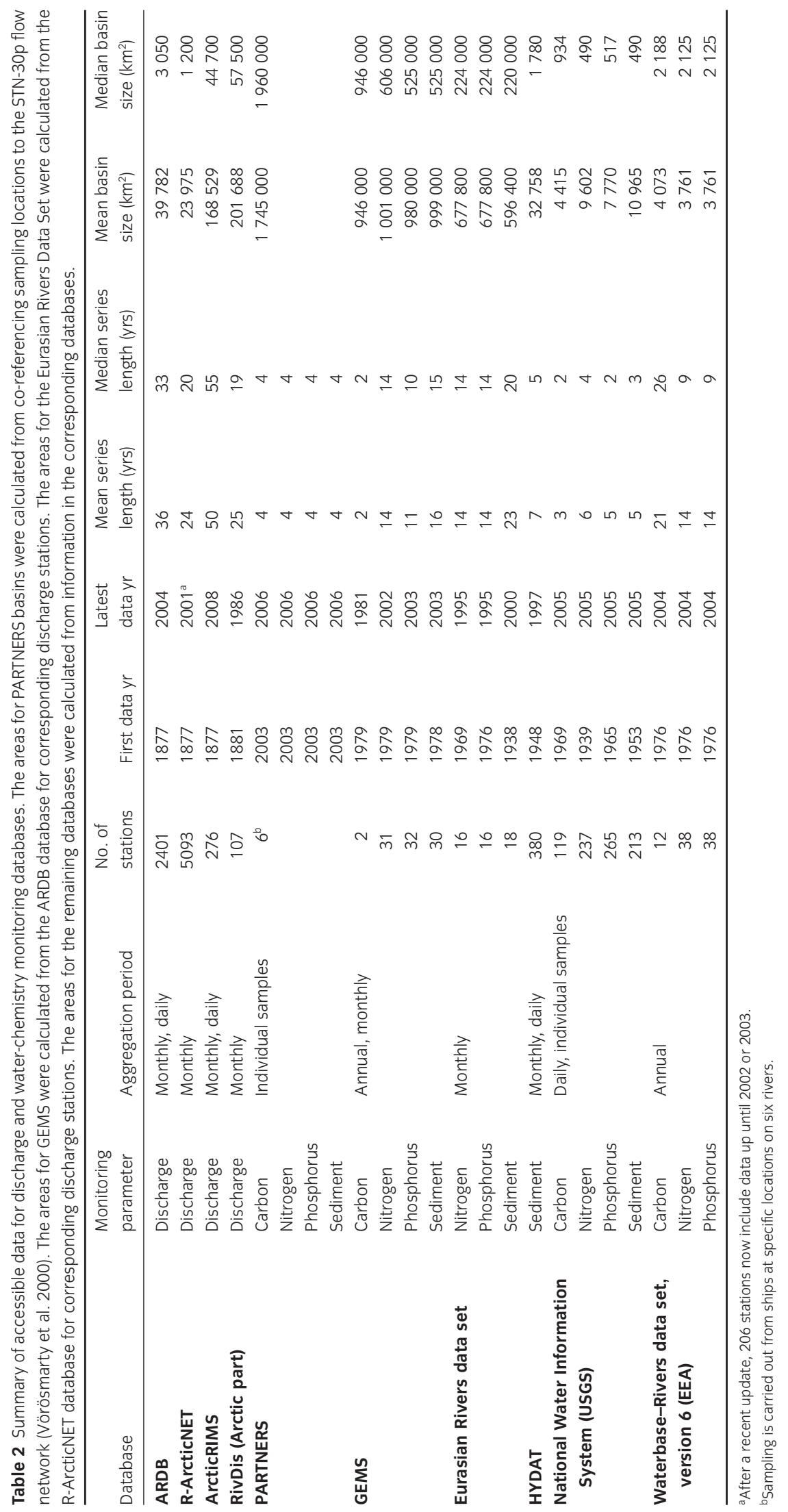


Fig. 1 Overview of the maximum length of accessible data series (years) for the panArctic monitoring of (a) water discharge, (b) carbon, (c) nitrogen, (d) phosphorus and (e) sediment. Cells containing stations with drainage areas smaller than five cells are indicated as partly monitored.
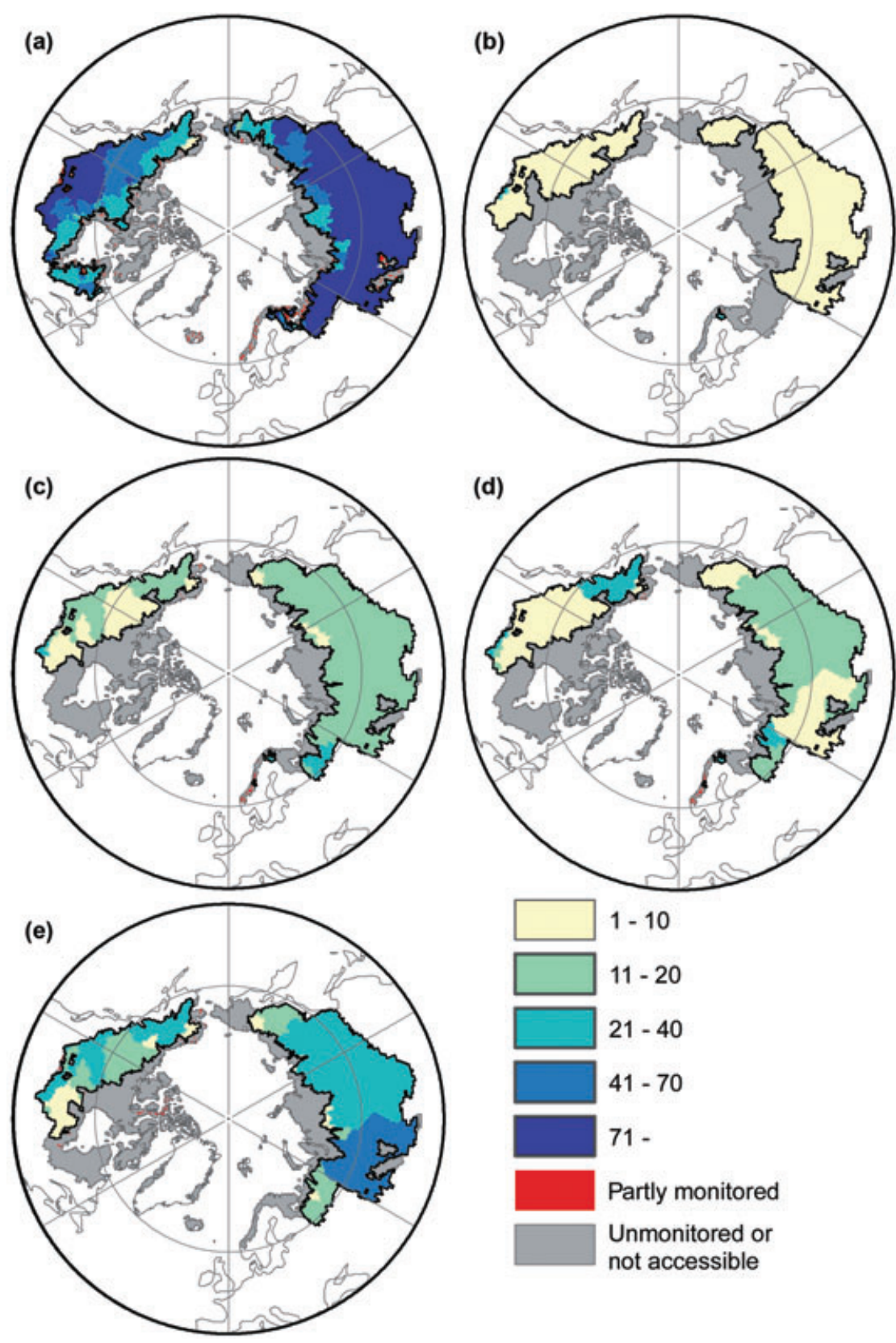

$11-20$

$21-40$

$41-70$

71 -

Partly monitored

Unmonitored or not accessible

motives for both the design of the various station networks and the subsequent choices of the stations from which data is made accessible.

Unfortunately, the variation in these factors implies that although the combined monitoring area of all databases for a certain monitoring parameter is relatively large, the data themselves may be difficult to combine. For example, a lowest common denominator of yearly data suffices to detect some long-term trends, but the study of processes on seasonal or shorter time scales, or the use of statistical techniques to identify shifts in hydro- logic behaviour (e.g., Lyon et al. 2009), requires a finer temporal resolution. In some cases there may be data with higher temporal resolution available, but not made accessible, and efforts at making such data accessible would clearly contribute to the possibility of combining data sets.

Furthermore, for the majority of the PADB, waterchemistry monitoring data are only accessible for very large basins, spanning climate zones and with heterogeneous properties. This is particularly true for the Asian territory, where there is no accessibility to the smaller 

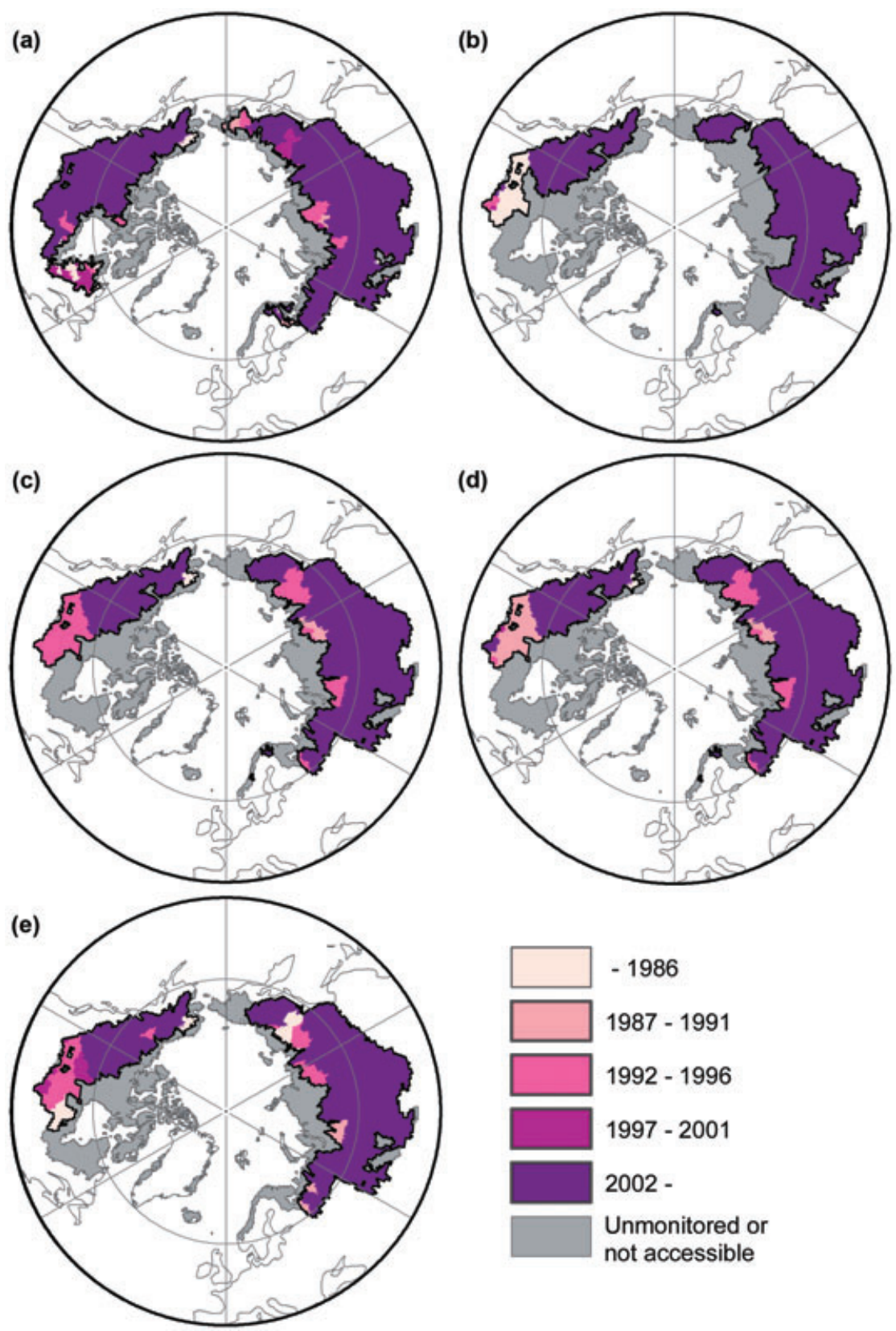

Fig. 2 Overview of the latest accessible data year for the pan-Arctic monitoring of (a) water discharge, (b) carbon, (c) nitrogen, (d) phosphorus and (e) sediment.

catchments that dominate European and North American water-chemistry monitoring at the regional and national levels. These differences indicate the difficulty in understanding biogeochemical responses at relatively small scales across the PADB. Further studies are required to specifically outline areas where an increased accessibility to data or the establishment of new stations is particularly important.

To realize the potential of combining monitoring data for the PADB, integration and the harmonization of data are important. This is a particularly challenging task for water-chemistry data, where measurement and analysis methods differ more widely than for discharge data. Globally, the United Nations GEMS/Water programme is a hydrochemical counterpart to the Global Runoff Data Centre, and aims to integrate and disseminate waterchemistry data. However, the GEMS/Water database does not currently function fully as a water-chemistry repository for the PADB. The GEMS/Water river station network in the PADB includes only 20 stations, several of which are clustered closely together in smaller areas. Furthermore, online data access is only possible though 
Fig. 3 Quotients of area-weighted average characteristic values of water discharge, carbon, nitrogen, phosphorus and sediment between unmonitored and monitored areas, for different continents in the pan-Arctic drainage basin. Quotients are not applicable for built-up land, temperate grasslands and continuous permafrost in European carbon monitoring, as the average value is zero for these parameters in monitored areas.

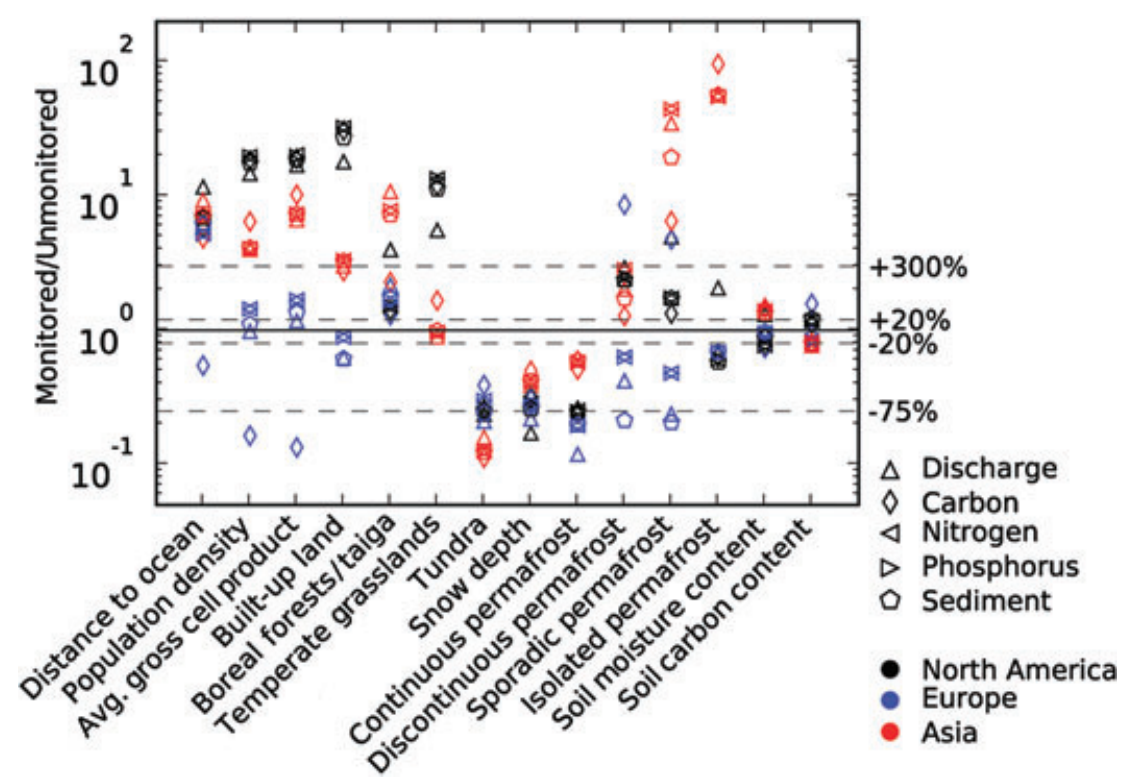

summary graphs, and the accessibility to recent data is relatively low. Developing a coherent and harmonized database of pan-Arctic water-chemistry data could improve the accessibility to data, and facilitate their use across a wider range of applications. Although it does not aim to integrate external data, the PARTNERS project provides access to pan-Arctic harmonized data, and is an important step in this direction.

Our analysis of the combined spatial and temporal extent of monitored areas shows that the majority of unmonitored areas are in the coastal high-latitude regions of the PADB (Figs. 1, 2). Although it is not surprising (nor perhaps undesirable) that stations are concentrated at lower latitudes, which coincides with the distribution of population, and also with most man-made water infrastructure (Lammers et al. 2001), the lack of monitoring around the coastal areas of the Arctic is problematic for at least three reasons.

Firstly, as a result of a warming climate, and the associated increased accessibility to natural resources and the Northern sea routes (Kerr 2002), the economic activity in high-latitude areas is expected to increase significantly in the future (Nellemann et al. 2001). Much of this increase will probably take place in coastal areas (Andreeva 1998). The hydrologic impacts of anthropogenic activities, such as hydrocarbon exploration, mining operations and forestry, might be significant in some areas, such as the observed doubling of sediment yield in the Kolyma River, which may be connected to gold mining (Gordeev 2006). With the coastal areas largely unmonitored, the impacts on water chemistry, solute fluxes and run-off regimes from these activities will remain largely unknown.
Secondly, the land-to-sea export of important waterchemistry constituents from near-coastal areas and smaller river basins may in some areas be significant in relation to the fluxes in major monitored rivers (Destouni et al. 2008). Our knowledge of the nutrient dynamics for boreal and Arctic rivers is limited (Humborg et al. 2003), and, to improve the quantification of subsurface pathways and land-sea interactions in polar regions, there is a motivation for an increased effort in monitoring these northern areas.

Thirdly, the significant disparity and heterogeneity in hydrological properties between monitored and unmonitored areas (Fig. 3) limit the reliability of the important modelling efforts that must be used to fill in gaps in the data. The hydrological properties of the northern unmonitored areas stand out as particularly dissimilar with regard to permafrost extent, vegetation type and climatic conditions, and may thus suffer from bias in the land-to-sea flux estimates based on accessible monitoring data. Also, the considerable differences between Europe, North America and Asia in representative coverage of some monitoring parameters may confound intercontinent comparisons based on accessible monitoring data.

Extending monitoring to remote areas of the Arctic is costly. Our analysis indicates, however, that large areas of the PADB are discharge-monitored, but lack monitoring of any of the water-chemistry parameters studied. In these cases, and particularly for large rivers, it may be rational and economically feasible to extend waterchemistry monitoring to coincide with the most downstream gauging station. In some cases, data may also be available, just not accessible. Although 
considerable areas would still be unmonitored, this would nevertheless improve the possibility of closing mass budgets for a larger share of the PADB. Another possibility to improve monitoring may be to extend the ship-based sampling within the PARTNERS programme, which was originally initiated to address some of the problems in Arctic water-chemistry monitoring. More specific investigations of potential station or sampling locations, in combination with cost-benefit analyses, are required to address the viability of such efforts.

\section{Conclusions}

The fragmentation of water-chemistry monitoring data implies that environmental modellers, as well as policymakers and the public, have a restricted ability to integrate accessible data and accurately assess biogeochemical changes in the Arctic environment. Although the monitoring of land-to-sea fluxes of hydrochemical constituents has recently improved through the PARTNERS project, relatively large and potentially significant high-latitude coastal areas remain unmonitored, for which budgets of carbon, sediment and nutrients cannot be closed. The shorter time series, restricted accessibility to recent data and incomplete spatial coverage of water-chemistry measurements, relative to water-discharge measurements, still hampers the possible uses of the water-discharge data.

Furthermore, the significant disparity and heterogeneity between characteristic properties of monitored and unmonitored areas limit the possibility to generalize hydrological and hydrochemical impact assessments based on monitoring data. Systematic differences in the relative characteristics of monitored and unmonitored areas between continents may also imply that the continent-tocontinent differences found in such monitoring-based assessments may depend more on monitoring bias than on real differences between continents.

The reliable identification and understanding of landto-sea fluxes from the entire PADB, including highlatitude tundra and permafrost soils, requires extended monitoring in northern near-ocean areas, and harmonized and more ready access to data. Monitoring would need to be extended to better cover the anthropogenic pressures in the European and Western Siberian part of the pan-Arctic. In North America and Asia, monitoring should be extended to better represent the permafrost and vegetation types present on the northern rims of these continents.

Ideally, an international repository for Arctic waterchemistry monitoring data would need to be established, with assured up-to-date, harmonized and good-quality data. The PARTNERS data is an important step in this direction, as it provides harmonized data for large parts of the pan-Arctic, but it does not aim to integrate accessible data from other sources and from smaller basins. Clearly, such an effort would still fall short of providing the same information level as the water-discharge monitoring, because the water chemistry records extend much shorter into the past than the water-discharge records. However, even with the coarser resolution and shorter time series of water chemistry, such a database would still be a valuable asset to environmental modellers and policymakers, facilitating the rapid dissemination of information on the changing Arctic environment, and allowing for better informed decisions to manage these changes.

\section{Acknowledgements}

We thank Fredrik Hannerz for many helpful suggestions and inputs to the data search. We also thank the reviewers for comments that have improved the manuscript. The work has been supported by the Swedish Research Council and the Swedish Research Council for Environment, Agricultural Sciences and Spatial Planning (Formas), and has been carried out as part of the Bert Bolin Centre for Climate Research at Stockholm University.

\section{References}

ADIS 2006. Arctic Climate System Study Data and Information Service. Accessed on the internet at http://acsys.npolar.no/adis/adis.php on 12 December 2006.

Andreeva E.N. 1998. The Russian Arctic coastal zone management problems: past lessons and new realities. Ocean e Coastal Management 41, 237-256.

ArcticRIMS 2007. ArcticRIMS. Accessed on the internet at http://rims.unh.edu on 11 January 2007.

Berezovskaya S., Yang D. \& Kane D.L. 2004. Compatibility analysis of precipitation and runoff trends over the large Siberian watersheds. Geophysical Research Letters 31, article no. L21502, doi 10.1029/2004GL021277.

Brown J., Ferrians O. Jr., Heginbottom J. \& Melnikov E. 1997. Circum-Arctic map of permafrost and ground-ice conditions. USGS Circum-Pacific Map Series CP-45. Reston, VA: US Geological Survey.

Brown J., Ferrians O.J. Jr., Heginbottom J.A. \& Melnikov E.S. 1998 (revised February 2001). Circum-Arctic map of permafrost and ground-ice conditions. Boulder, CO: National Snow and Ice Data Center/World Data Center for Glaciology. Digital media.

Brown K. 2002. Water scarcity: forecasting the future with spotty data. Science 297, 926-927.

CIESIN (Center for International Earth Science Information Network) 2007. Gridded Population of the World, 
version 3 (GPW v3). Accessed on the internet at http:// sedac.ciesin.columbia.edu/gpw/ on 19 March 2007.

Destouni G., Hannerz F., Prieto C., Jarsjö J. \& Shibuo Y. 2008. Small unmonitored near-coastal catchment areas yielding large mass loading to the sea. Global Biogeochemical Cycles 22, article no. GB4003, doi 10.1029/2008GB003287.

Environment Canada 2004. HYDAT version 2004-20.04. Ottawa: Water Survey of Canada. Accessed on the internet at http://www.wsc.ec.gc.ca/products/hydat/main_e. cfm?cname=hydat_e.cfm on 14 March 2007.

European Environment Agency 2006. Waterbase-Rivers dataset, version 6. Accessed on the internet at http:// dataservice.eea.europa.eu/dataservice/metadetails. asp?id=835 on 4 February 2007.

Fekete B.M. \& Vörösmarty C.J. 2002. The current status of global river discharge monitoring and potential new technologies complementing traditional discharge measurements. In D. Schertzer et al. (eds.): Predictions in Ungauged Basins: PUB kick-off (Proceedings of the PUB kick-off meeting held in Brasilia, 20-22 November 2002). IAHS Publication 349. Paris: International Association of Hydrological Sciences.

GCOS (Global Climate Observing System) 2005. Analysis of data exchange problems in global atmospheric and hydrological networks. GCOS Report 96. Geneva: World Meteorological Organization.

GEMStat 2007. GEMStat: Global Water Quality Database. Accessed on the internet at http://www.gemstat.org on 10 February 2007.

Global Soil Data Task Group 2000. Global gridded surfaces of selected soil characteristics (International Geosphere-Biosphere Programme Data and Information System). Data set. Accessed on the internet at http:// www.daac.ornl.gov on 24 April 2007.

Gordeev V.V. 2006. Fluvial sediment flux to the Arctic Ocean. Geomorphology 80, 94-104.

GOSIC (Global Observing Systems Information Centre) 2006. Global Observing Systems Information Centre. Accessed on the internet at http://www.gosic.org on 11 December 2006.

GRDC (Global Runoff Data Centre) 2006. Global Runoff Data Centre. Accessed on the internet at http://grdc.bafg.de on 5 December 2006.

Hannerz F. 2008. Making water information relevant on local to global scale - the role of information systems for integrated water management. PhD thesis, Stockholm University.

Hinzman L.D., Bettez N.D., Bolton W.R., Chapin F.S. III, Dyurgerov M.B., Fastie C.L., Griffith B., Hollister R.D., Hope A., Huntington H.P., Jensen A.M., Jia G.J., Jorgenson T., Kane D.L., Klein D.R., Kofinas G., Lynch A.H., Lloyd A.H., McGuire A.D., Nelson F.E., Oechel W.C., Osterkamp T.E., Racine C.H., Romanovsky V.E., Stone R.S., Stow D.A., Sturm M., Tweedie C.E., Vourlitis G.L., Walker M.D., Walker D.A., Webber P.J., Welker J.M., Winker K.S. \& Yoshikawa K. 2005. Evidence and implications of recent climate change in northern Alaska and other Arctic regions. Climatic Change 72, 251-298.
Holmes R.M., McClelland J.W., Peterson B.J., Shiklomanov I.A., Shiklomanov A.I., Zhulidov A.V., Gordeev V.V. \& Bobrovitskaya N.N. 2002. A circumpolar perspective on fluvial sediment flux to the Arctic Ocean. Global Biogeochemical Cycles 16, article no. 1098, doi 10.1029/ 2001 GB001849.

Holmes R.M. \& Peterson B.J. 2002. Eurasian river historical nutrient and sediment flux data. Boulder, CO: National Snow and Ice Data Center. Digital media. Accessed on the internet at http://nsidc.org/data/arcss092.html on 14 February 2007.

Holmes R.M., Peterson B.J., Gordeev V.V., Zhulidov A.V., Meybeck M., Lammers R.B. \& Vörösmarty C.J. 2000. Flux of nutrients from Russian rivers to the Arctic Ocean: can we establish a baseline against which to judge future changes? Water Resources Research 36, 2309-2320.

Holmes R.M., Peterson B.J., Zhulidov A.V., Gordeev V.V., Makkaveev P.N., Stunzhas P.A., Kosmenko L.S., Köhler G.H. \& Shiklomanov A.I. 2001. Nutrient chemistry of the $\mathrm{Ob}^{\prime}$ and Yenisey Rivers, Siberia: results from June 2000 expedition and evaluation of long-term data sets. Marine Chemistry 75, 219-227.

Houghton J.T., Ding Y., Griggs D.J., Noguer M., van der Linden P.J., Dai X., Maskell K. \& Johnson C.A. (eds.) 2001. Climate change 2001: the scientific basis. Contribution of Working Group I to the third assessment report of the Intergovernmental Panel on Climate Change. Cambridge: Cambridge University Press.

Humborg C., Danielsson Å., Sjöberg B. \& Green M. 2003. Nutrient land-sea fluxes in oligotrophic and pristine estuaries of the Gulf of Bothnia, Baltic Sea. Estuarine, Coastal and Shelf Science 56, 781-793.

Kerr R.A. 2002. A warmer Arctic means change for all. Science 297, 1490-1492.

Lammers R.B., Shiklomanov A.I., Vörösmarty C.J., Fekete B.M. \& Peterson B.J. 2001. Assessment of contemporary Arctic river runoff based on observational discharge records. Journal of Geophysical Research-Atmospheres 106, 3321-3334.

Lyon S.W., Destouni G., Giesler R., Humborg C., Mörth M., Seibert J., Karlsson J. \& Troch P.A. 2009. Estimation of permafrost thawing rates in a sub-Arctic catchment using recession flow analysis. Hydrology and Earth System Sciences Discussions 6, 63-83.

Maurer T. 2003. Development of an operational internet-based near real time monitoring tool for global river discharge data. GRDC Report 30. Koblenz: Global Runoff Data Centre.

McClelland J.W., Holmes R.M., Peterson B.J., Amon R., Brabets T., Cooper L., Gibson J., Gordeev V.V., Guay C., Milburn D., Staples R., Raymond P.A., Shiklomanov I., Striegl R., Zhulidov A., Gurtovaya T. \& Zimov S. 2008. Development of a pan-Arctic database for river chemistry. EOS, Transactions of the American Geophysical Union 89, doi 10.1029/2008EO240001.

Miteva B. 2001. Built-up land classification. Accessed on the internet at http://www.sage.wisc.edu/atlas/ maps.php?datasetid=188dataset $=18$ on 19 April 2007 . 
Nellemann C., Kullerud L., Vistnes I., Forbes B.C., Husby E., Kofinas G.P., Kaltenborn B.P., Rouaud J., Magomedova M., Bobiwash R., Lambrechts C., Schei P.J., Tveitdal S., Grøn O. \& Larsen T.S. 2001 GLOBIO. Global methodology for mapping human impacts on the biosphere. UNEP/DEWA/ TR.01-3. Nairobi: Division of Early Warning and Assessment, United Nations Environment Programme.

Nordhaus W.D. 2006. Geography and macroeconomics: new data and new findings. Proceedings of the National Academy of Sciences 103, 3510-3517.

NSIDC (National Snow and Ice Data Center) 2006. National Snow and Ice Data Center. Accessed on the internet at http://nsidc.org on 15 December 2006.

Olson D.M., Dinerstein E., Wikramanayake E.D., Burgess N.D., Powell G.V.N., Underwood E.C., D'amico J.A., Itoua I., Strand H.E., Morrison J.C., Loucks C.J., Allnutt T.F., Ricketts T.H., Kura Y., Lamoreux J.F., Wettengel W.W., Hedao P. \& Kassem K.R. 2001. Terrestrial ecoregions of the world: a new map of life on Earth. BioScience 51, 933-938.

PARTNERS 2008. Pan-Arctic River Transport of Nutrients, Organic Matter, and Suspended Sediments. Accessed on the internet at http://ecosystems.mbl.edu/partners on 16 June 2008.

Peterson B.J., Holmes R.M., McClelland J.W., Vörösmarty C.J., Lammers R.B., Shiklomanov A.I., Shiklomanov I.A. \& Rahmstorf S. 2002. Increasing river discharge to the Arctic Ocean. Science 298, 2171-2173.

Peterson B.J., McClelland J., Curry R., Holmes R.M., Walsh J.E. \& Aagaard K. 2006. Trajectory shifts in the Arctic and Subarctic freshwater cycle. Science 313, 1061-1066.

Prowse T.D., Bøggild C.E., Glazovsky A.F., Hagen J.O.M., Hinzman L.D., Killingtveit Å., Lettenmaier D.P., Nelson F.E., Rouse W.R., Steffen K., Shiklomanov I.A., Young K.L. \& Kotlyakov V.M. 2005. ICARP II-Science Plan 7. Terrestrial cryospheric and hydrologic processes and systems. Copenhagen: Second International Conference on Arctic Research Planning.

SAGE (Center for Sustainability and the Global Environment) 2007. Atlas of the biosphere: mapping the biosphere. Accessed on the internet at http:// www.sage.wisc.edu/atlas/maps.php on 30 March 2007.

Serreze M.C., Walsh J.E., Chapin III F.S., Osterkamp T., Dyurgerov M., Romanovsky V., Oechel W.C., Morison J., Zhang T. \& Barry R.G. 2000. Observational evidence of recent change in the northern high-latitude environment. Climatic Change 46, 159-207.

Shiklomanov A.I., Lammers R.B. \& Vörösmarty C.J. 2002. Widespread decline in hydrological monitoring threatens
pan-Arctic research. EOS, Transactions of the American Geophysical Union 83, 13.

Sidle D.R.C. 2006. Field observations and process understanding in hydrology: essential components in scaling. Hydrological Processes 20, 1439-1445.

Soulsby C., Tetzlaff D., Dunn S.M. \& Waldron S. 2006. Scaling up and out in runoff process understanding: insights from nested experimental catchment studies. Hydrological Processes 20, 2461-2465.

US Geological Survey 1998. HYDRO1k Elevation Derivative Database. Center for Earth Resources Observation and Science, Sioux Falls, SD.

US Geological Survey 2007. USGS National Water Information System. Accessed on the internet at http:// waterdata.usgs.gov/nwis on 20 March 2007.

Vörösmarty C.J., Fekete B.M., Meybeck M. \& Lammers R.B. 2000. Global system of rivers: its role in organizing continental land mass and defining land-to-ocean linkages. Global Biogeochemical Cycles 14, 599-621.

Vörösmarty C.J., Fekete B.M. \& Tucker B.A. 1998. River Discharge Database, version 1.1 (RivDIS v1.0 supplement.) Available through the Institute for the Study of Earth, Oceans, and Space, University of New Hampshire, Durham, NH.

Vörösmarty C.J., Hinzman L.D., Peterson B.J., Bromwich D.H., Hamilton L.C., Morison J., Romanovsky V.E., Sturm M. \& Webb R.S. 2001. The hydrologic cycle and its role in Arctic and global environmental change: a rationale and strategy for synthesis study. Fairbanks: Arctic Research Consortium of the United States.

Walker T.R., Crittenden P.D., Young S.D. \& Prystina T. 2006. An assessment of pollution impacts due to the oil and gas industries in the Pechora basin, north-Eastern European Russia. Ecological Indicators 6, 369-387.

Walsh J., Anisimov O., Hagen J.O., Jakobsson T., Oerlemans J., Prowse T.D., Romanovsky V., Savelieva N., Serreze M., Shiklomanov A., Shiklomanov I. \& Solomon S. 2005. Crysophere and hydrology. In C. Symon et al. (eds.): Arctic climate impact assessment. Pp. 183-242. Cambridge: Cambridge University Press.

Willmott C.J. \& Matsuura K. 2001. Terrestrial water budget data archive: monthly time series (1950-1999). Accessed on the internet at http://climate.geog.udel.edu/ climate/ html_pages/download.html on 30 April 2007.

Zhulidov A.V., Khlobystov V.V., Robarts R.D. \& Pavlov D.F. 2000. Critical analysis of water quality monitoring in the Russian Federation and former Soviet Union. Canadian Journal of Fisheries and Aquatic Sciences 57, 1932-1939. 